\title{
INNOVATIVE ENVIRONMENT IN UKRAINE: FORMATION AND EVALUATION OF DEVELOPMENT IN THE CONDITIONS OF THE BALANCED ECONOMIC GROWTH
}

\author{
Diana Zavadska \\ Department of Banking \\ Odessa National Economic University, \\ 8 Preobrazhenska str., Odessa, Ukraine, 65082 \\ zavadska.diana@ukr.net
}

\begin{abstract}
The paper notes that the success of economic policy aimed at forming a new model of Ukraine's economic growth is facilitated by a clear choice of priorities, among which the main thing is to ensure high rates of sustainable economic growth.

The main components of the innovative environment of the economy are determined. The analysis of indicators of innovative development of the countries of the world for the period 2011-2017 is carried out using the Principal Components and Classification Analysis method in the Statistica 10.0 software package. The factors of influence on the innovative development of countries are determined. The advantages of structuring the innovative environment are determination of the subordination of priorities for supporting innovations by the state, business and financial market.

In the course of the research, methods of systemic, theoretical generalization, analysis, comparative comparison, tabular and graphical presentation of results are used, which allows the author to prove a low level of regulation of the innovation process characteristic of the Ukrainian economy. The problems of innovative development of groups of countries with low and above average level of income according to the World Bank classification are characterized by the lack of a developed innovative environment, the implementation of the secondary role of the state as a component of the national innovative system.

The peculiarity of state regulation of high-income countries is determined by the balance of innovation policy instruments. The presence of a developed institutional environment (fundamental conditions) ensures the effectiveness of financial support of the business, obtaining high results from innovations and retaining the leading position on innovative development.

At the decision of the enterprises of a group of countries with a level of incomes above the average for the implementation of investments in innovative activities and further innovative development, financial markets, commodity markets and the effectiveness of the legal system are of greatest importance. It is proved that for the low-income countries the variable "Market development" has a stimulating significance for economic growth.

The above, as well as fragmentation, the definition of factors of innovative development according to the Global Innovation Index, provided grounds for the author to give recommendations (integral indicator) in determining the priority of development of the content elements of the national innovative system, highlighting the importance of the state, human capital, research, financial and commodity markets in economic growth of the country, identifying sources and priorities for financing innovative development.

Keywords: state, economy, development, environment, innovation, policy, evaluation.
\end{abstract}

\section{Introduction}

In a difficult economic situation, ensuring long-term sustainable economic development for Ukraine is a top priority. Restoration of socio-economic growth after the stagnation and recession of 2013-2017 due to the exhaustion of the potential of the export-raw material development model, the poor quality of the institutional environment, underinvestment of R\&D and investment in production, the rapid aging of the material and technical base of the economy, the crisis in the scientific sphere leading schools and scientific and technical complexes in the sphere of fundamental sciences, the outflow of scientific personnel abroad), the orientation toward the strategy of import substitution, the instability of the banking system themes and more challenging than for Ukraine to overcome the 2009 crisis. Ukraine is viewed as a country in the second, investment stage of development, according to which competitiveness is achieved through increased labor productivity, the ability to attract technology and capital, improving product quality and optimizing costs. This means that the efficiency and elasticity of the market, the commodity market, the labor market, the country's ability to attract investments and invest in human capital are important for increasing the competitiveness of the economy. 
To ensure sustainable economic development, the conceptual rethinking of state economic policy, in particular innovation policy, is topical. Unbalanced innovative policy of the state has a negative impact on setting the goals of the national innovative system, the efficiency of the allocation of financial resources, the interaction of elements of the innovative environment, slows down innovative development and leads to the loss of competitiveness of the economy.

Despite the fact that the economic growth and development of the innovative environment is the subject of scientific research of many scientists, the analysis of recent publications convincingly shows that the issues of ensuring the interaction of public authorities, the formation of a national innovative system, determining the impact of innovation on economic growth and labor productivity remain important.

So, according to the author [1], "In the era of globalization of the economy, the informatization of society and the formation of innovative models of socio-economic development of national economies, the innovative environment becomes a key source of innovation that provides:

- accelerating and increasing the efficiency of the processes of creating innovations from the idea to the beginning of production, in particular, due to the ability of the innovative environment to generate synergy at interfunctional and multi-institutional levels;

- increase in value added in the production of innovative products or with the use of innon vations in the production process;

- increase in speed and expansion of the boundaries of diffusion of innovations in the disi tribution process.

In these conditions, when forming an innovative environment, it is necessary to ensure its organic inclusion in all phases of the reproduction cycle: "production-distribution-exchange-consumption".

According to the author's opinion [2] "the active role of the state lies in: orientation to innovation on its own basis, organization and finance of the fundamental science, risk applied research; import substitution using own developments; refusal from broad support of traditional export industries, improvement of institutional conditions due to the reduction of regulatory functions of the state and stimulation of business ".

The author [3] notes that "at the macroeconomic level, the growth of labor productivity determines the dynamics of GDP, provides an increase in the purchasing power of the bulk of the population, becomes an effective means of weakening inflation and the main source of activities aimed at social development and the growth of living standards."

According to the opinion of author [4], "The central aim of most research on Innovation Systems has been to reveal how differences in configurations as well as interactive learning processes of the respective actors and institutions are responsible for particular (knowledge-based) economic outcomes. Much of Innovation Systems research has focused on analyzing how generic innovation capabilities can be strengthened. The first central question "what" to transform or sustain concerns the overarching issue of directionality or goal-orientation of Innovation Systems. Directionality primarily involves the question "What is the ultimate goal of an Inm novation System?" In the context of sustainability, it is also a question of "the right" transformation pathway(s) for social, economic, ecological, cultural, technological, and other relevant (sub-) systems. Therefore, directionality is not only about challenging the contemporary imf plicit focus on technological innovation and economic growth but also about opening up the Innovation System approach for a variety of pathways and actors while closing down other, non-sustainable options".

According to the opinion of author [5],"The innovation environment comprehends institue tions which, together and individually, contribute to the development and dissemination of new information and new technologies and which comprise a structural and legal framework, on which the government executes policies promoting innovation. The innovation environment consists of structures, actors, reciprocalities and a legally created operating environment. In addition to these, other key elements include an innovation culture, processes that inspire individuals and organizations to create the new, global information channels as well as shared innovation knowledge and interpretative frames of reference". 
According to [6], "conditions for investment have generally improved, amid low financial volatility, reduced banking sector fragilities, recovery in some commodity sectors and a more solid global macroeconomic outlook. Financing costs generally remain low, and spreads have narrowed in many emerging markets, reflecting a decline in risk premia. This has supported rising capital flows to emerging markets, including a rise in cross-border lending, and stronger credit growth in both developed and developing economies".

It is reported that "science, technology and innovation have long been important drivers of economic growth and human development. Growth relies on the integration of basic and applied research, at both public and private levels, on an international scale. The challenge is to ensure that, even during phases of economic slowdown, science and technology continue to support the objectives of sustainability and improved living standards in all countries. Institutional arrangements are needed to make sure that the potential of science and technology is aligned with the paths and strategies of economic development, social inclusion and environmental sustainability, are argued by the United Nations report, "Transforming our world: the 2030 Agenda for Sustainable Development" [7].

As the author [8] notes, "although monetary and fiscal policy is implemented by two different state bodies, they are not independent. Changes in one of the bodies will affect the effectiveness of the work of the other and, thus, will have a general effect on changes in any policy. Tensions can arise between how each of the policies will help smooth the economic cycles, achieve macroeconomic stability and growth".

The inability of central banks to raise inflation expectations at zero bottom threshold, the lack of coordination between monetary authorities and fiscal authorities ... interact inappropriately to achieve the desired level of inflation [9].

\section{The aim of research}

The aim of research is development of recommendations for determining the priorities of the state innovative policy and assessing the innovative environment in the context of balanced economic growth in Ukraine. Solving the goal contributes to the following tasks:

1. To substantiate the content and sequence of stages of balanced economic growth in Ukraine.

2. To present the components of the innovative environment and the hierarchy of priorities of the state innovation policy.

3. To identify the relationship between the main variables that characterizes the innovative activity and the long-term consequences of innovation for the country.

\section{Materials and methods}

To solve the set tasks, the following methods are used: systematic, theoretical generalization, analysis, comparative comparison, tabular and graphical presentation of research results.

The information base of the research is made by scientific works of Ukrainian and foreign scientists on the investigated problem. The official statistical base is made up of data from the annual reports of international organizations for 2011-2017.

\section{Results}

The main condition for the growth of public life is the modernization of the Ukrainian economy. In 2010, Ukraine officially announced the transition to an innovative development model aimed at increasing national competitiveness. The success of economic policy aimed at forming a new model of Ukraine's economic growth is facilitated by a clear choice of priorities, among which, in our view, the main thing is to ensure high rates of sustainable economic growth in the following order:

- restoration of economic growth (increase in revenues from traditional exports, containi ment of excessive strengthening of the hryvnia exchange rate, re-loading of existing competitive capacities);

- access to high rates and quality of economic growth (increase in labor productivity and competitiveness of the economy, expansion of non-primary exports, market strengthening of the 
hryvnia exchange rate, stimulation of investments in basic and human capital, growth of the accumulation rate, expenditure on education, science and health);

- sustainable development (improvement of the quality of life, development of non-primam ry high-tech exports, new markets for innovative products, convergence of the parameters of the nominal exchange rate and PPP, development of global innovation markets, management of global production chains).

Prospects for ensuring high rates of sustained economic growth depend on the potential of the innovative environment at each of the stages of its development defined above.

According to expert assessments of the World Economic Forum, the peculiarities of the current stage of Ukraine's development caused by the specifics of industrialization processes, the weakness of the economic system, the underdevelopment of the financial and consumer market, form a number of challenges, including: inefficient state management, inaccessibility of financial resources through a credit mechanism and critical scales and rates loss of human capital.

It should be noted that only the state can be the initiator of balanced economic growth of Ukraine. The general influence of the state can be estimated at $80 \%$. However, this assessment will be effective in the conditions of high rates of annual economic growth (at a level of not less than $10 \%$ [10]), ensured by the interaction of public authorities as a single economic complex - coordination of monetary measures (changing the mechanism of money supply, the use of the mechanism of lending rates, incentives savings and raising the rate of accumulation) and fiscal (the creation of macroeconomic stability and the stability of public finances) policies as factors in providing eco resources development (investment promotion).

Accumulating resources, in particular knowledge, is the driving force behind balanced economic growth. Research, accumulation of human capital (education and training) play an important role in ensuring per capita income growth in the long term [11], since the higher the level of human capital that the country has, the higher the productivity of labor, ensures a sustainable level and the quality of economic growth. Therefore, the formation of an innovative environment (the basic conditions for social life and the conditions for the emergence of research), the opportunities for effective use of resources in priority areas of development of the Ukrainian economy, is urgent.

The experience of economically developed countries shows that the economic progress of society is provided by innovations, as a result of the combination of the possibilities of scientific and technological progress with economic needs. To develop innovations, it is necessary to have an environment favorable for scientists, entrepreneurs and innovators. This thesis is widely recognized and formulated in strategic documents of countries that have reached a high level of innovative development. Therefore, for the purposes of our research, it is proposed to structure the notion of an "innovative environment", define a hierarchy and study the priority of the main instruments of Ukraine's innovative policy in comparison with the countries of the world.

An innovative environment is a combination of internal factors and external conditions of participants in innovative activity that are formed by the interaction of interrelated socio-economic elements and provide a synergetic effect aimed at generating innovations (Fig. 1).

The internal environment of innovations reflects the availability of opportunities for effective use of resources, the fulfillment of the target task and depends on the company's innovation climate (atmosphere, culture) and the external environment, contributes to or hinders innovative development.

The national innovative system is characterized by a given structure and a certain degree of ordering, which provides for sufficient stability of institutional interaction [14, 15]. The national innovative system consists of two main elements:

- organizations, formal structures, consciously created to realize a specific goal. They are the main subjects of the innovation process [16] (higher education institutions, research organizations, venture funds and government agencies that develop and implement innovative policies);

- institutions of state regulation, which are a system of generally accepted rules, legislative acts regulating relations between individuals, groups and organizations [17]. The state pursues a policy in the field of innovation, forms mechanisms for interaction between actors within the innovative system, creates prerequisites for accelerated overflow of knowledge and technology between them, which, in our opinion, determines the overall effectiveness of the national innovative system. 


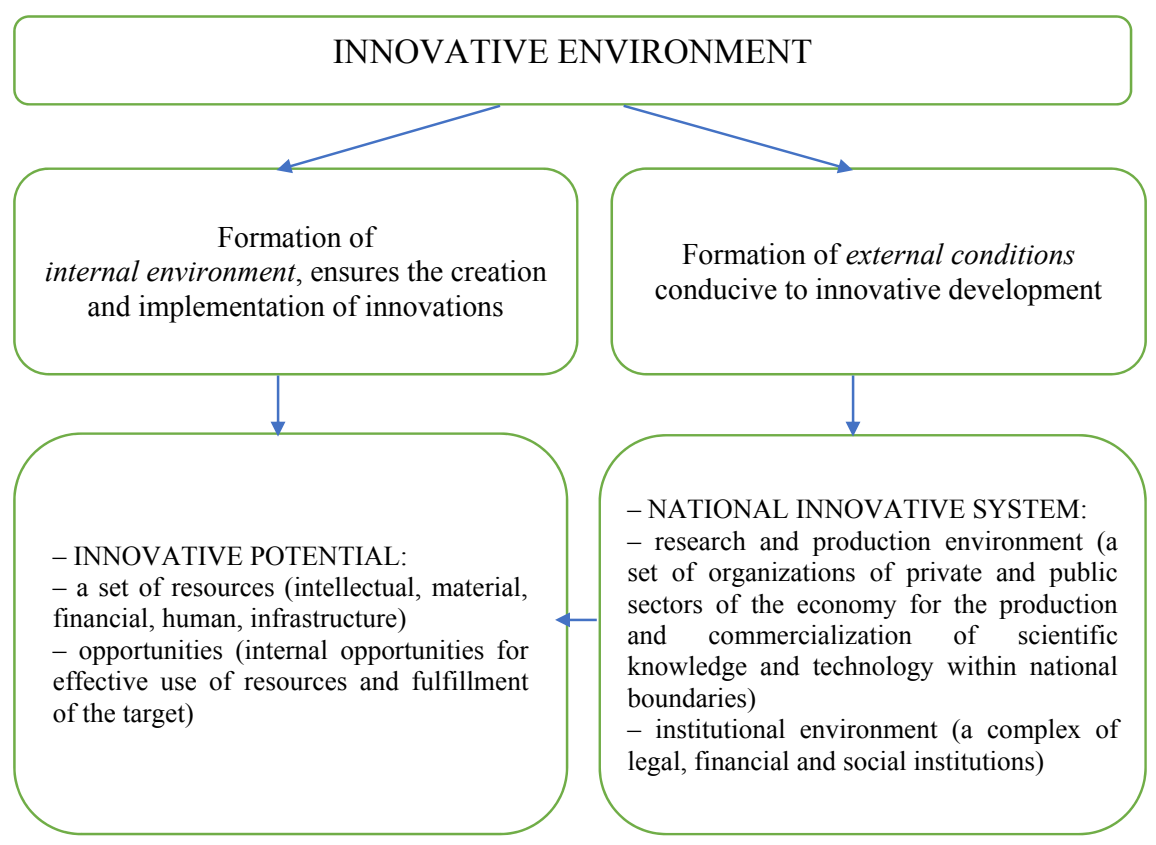

Fig. 1. Components of the innovative environment. Compiled by the author on the basis of sources $[12,13]$

Within the framework of innovative policy, public authorities determine the objectives of the innovative strategy and mechanisms for supporting priority innovative programs and projects (direct financial support for innovative processes, fiscal incentives for innovators, legal, infrastructure, economic and political tools to support innovation).

The hierarchy of priorities of the state innovation policy can be represented by the largest content elements of the national innovative system, arranged in the following hierarchical structure:

- the basic institutions of the state (basic conditions for public life: public, political, ecoe nomic);

- knowledge (conditions for the emergence of research: general education, higher education, research and development);

- culture (conditions for development: the relevance of innovation, the prestige of innovat tion, the vision of the future);

- infrastructure (conditions for activities: physical/territorial, information, logistics);

- markets (commercialization: financial, technological, intellectual);

- financing of basic research (grants, scholarships, prizes, equipment);

- financing of innovative companies (direct financing, indirect financing instruments).

An intermediate but significant result of the development of all components of the national innovative system is the availability and activity of the innovation process. At this level, programs of fundamental scientific research and innovative development are developed for a long-term period, industry and technological priorities are determined for further government support:

- innovative activity (organization-innovators, employment in innovations);

- innovative results (innovative products, created technologies, obtained patents, profits, capitalization).

Long-term consequences for the economy and society are innovative development and economic growth, the interrelation of which is determined by the increase in labor productivity and production efficiency in all sectors of the economy:

- long-term consequences of innovation (sustainable economic development, country leada ership in international markets, growth of aggregate factor productivity and living standards).

As noted earlier, innovative development of the country depends on the development degree of the components of the national innovative system. Priorities of innovative policy should be directed, first of all, to the formation of a system of development institutions, the creation of 
technological platforms, the development and implementation of innovative projects, the upgrading of Ukraine's ratings in international ratings on innovative development. It is noteworthy that the concentration only on local achievements of innovative policy, in particular the search for sources of financing for individual projects, will entail only a slowdown in the country's innovative development and a backlog from the leading countries.

Formation of the innovative environment provides for a qualified management, built on information support. International organizations and analytical companies, in particular the World Bank and RAND Corporation, are assessing the level of innovative development of countries. The most famous measures of innovation in countries are:

- Global Innovation Index, analytical center of the Lausanne School of Business INSEAD, Switzerland (indicators of innovative development: the country's innovative potential and the conditions for its implementation) [18];

- Global Innovation Index BCG, Boston Consulting Group, USA (indicators of innovative development: conditions and factors of innovative development) [19];

- Innovation Capacity Index, International Research Structure of EFD, Global Consulting Network, Spain (indicators of innovation development: institutional environment, human capital, regulatory policy, feasibility of research and development, use of information and communication technologies) [20];

- Innovative index of the European innovation board (Summary Innovation Index), Europep an Commission PRO INNO EUROPE (indicators of innovative development: resources, opportunities, innovative activity of firms, results) [21].

The methods for calculating these indices differ significantly between each other in terms of purpose, methodology of calculation, the range of covered countries, the list and composition of indicators, the coverage degree of innovation results, the algorithm for integrating information, and the like.

For our further research let's use the data of the Global Innovation Index, as it is characterized by the complexity of determining the significance of innovative development of countries, creating an enabling environment for innovation and obtaining results from it. Index indicators are partial indicators, the estimated values of which are used to measure the innovative development of countries.

Proceeding from the fact that the national innovative system is determined by three key components, such as: the fundamental conditions that are provided by the state, the innovative activity and interaction of participants in order to achieve results that have economic and social values for society, let's estimate the relationship between the result of innovation (Innovation Output), the contribution of innovation (Innovation Input) and aggregate factor productivity (Growth Factor Productivity) using the Principal Components and Classification Analysis method in the software package Statistica 10.0. The criteria for selecting a particular country are the place in the international rating for innovative development and the level of income according to the World Bank classification. For the analysis, factors were used such as: institutions; human capital and research; infrastructure, market development, business development, knowledge and technology, output; creative release.

Table 1 presents a matrix of correlations between innovative contribution variables and the main components for each of the groups of countries. The method of the main components allows to explain the relationship between the variables by means of several factors that can't be directly measured. As a result of the factorization from the correlation matrix, a different number of factors were identified for each of the groups of countries. The factor matrix shows which variables each factor has generated.

According to the results of the analysis, the first three factors were determined, they correspond to the quality of the representation in the amount of $86.8 \%$ (Quality of representation $\geq 70 \%$, Numbers of factors $\geq 2$ ) for a group of high-income countries), $83.3 \%$ for a group of countries with a level income above the average and $80.9 \%$ for the group of countries with incomes below the average. Proceeding from the fact that the value of the factor load is significant, it is determined in the software package Statistica 10.0 at the level of 0.7 on the module, for the group of countries with 
a high level of income the factor matrix is represented by Factor 1 "Institutional environment and business" containing a set of such variables, such as "Institutions" and "Business Development".

For a group of countries with an income level above the average, the factor matrix is represented by Factor 1 "Scientific and production environment" ("Human capital and research", "Market development" and "Business development"). Factor 2 "Institutional environment" is represented by the variable "Institutes".

\section{Table 1}

Matrix of correlation of factors of innovative costs and total factor productivity of the countries of the world for the period of 2011-2017

\begin{tabular}{|c|c|c|c|}
\hline \multirow{2}{*}{$\begin{array}{l}\text { Variables } \\
\text { (Average value by countries) for correlation analysis }\end{array}$} & \multicolumn{3}{|c|}{ Factor coordinates of variables based on correlation } \\
\hline & Factor 1 & Factor 2 & Factor 3 \\
\hline \multicolumn{4}{|c|}{$\begin{array}{l}\text { The World Bank Group of High-Income Countries } \\
\text { (Sweden, USA, Great Britain, Singapore, Germany, South Korea) }\end{array}$} \\
\hline institutes & -0.86 & 0.16 & -0.15 \\
\hline human capital and research & -0.48 & -0.68 & 0.43 \\
\hline infrastructure & -0.24 & -0.68 & -0.67 \\
\hline market development & -0.65 & 0.45 & -0.35 \\
\hline business development & -0.86 & 0.06 & 0.36 \\
\hline Explained variation, $\%$ & 44.70 & 23.40 & 18.69 \\
\hline \multicolumn{4}{|c|}{ The World Bank Group of Above the Middle-Income Countries (China, Bulgaria, Malaysia, Romania, Turkey, Thailand } \\
\hline institutes & 0.06 & -0.92 & 0.36 \\
\hline human capital and research & -0.81 & -0.12 & 0.08 \\
\hline infrastructure & -0.41 & -0.35 & -0.82 \\
\hline market development & -0.86 & 0.07 & 0.13 \\
\hline business development & -0.80 & 0.15 & 0.23 \\
\hline Explained variation, \% & 44.80 & 20.60 & 17.84 \\
\hline \multicolumn{4}{|c|}{ The World Bank Group of Lower the Middle-Income Countries (Vietnam, Ukraine, Armenia, India, Philippines, Indonesi } \\
\hline institutes & -0.39 & -0.77 & 0.15 \\
\hline human capital and research & 0.71 & -0.46 & -0.14 \\
\hline infrastructure & -0.71 & 0.36 & 0.41 \\
\hline market development & -0.63 & -0.56 & 0.01 \\
\hline business development & 0.63 & -0.11 & 0.74 \\
\hline Explained variation, $\%$ & 39.76 & 25.69 & 15.46 \\
\hline
\end{tabular}

Note: calculated by the author according to sources [22-25]

For a group of countries with incomes below the average, the factor matrix is represented by Factor 1 "Research and Production Environment": ("Human Capital and Research" and "Infrastructure" and "Business Development"). Factor 2 "Institutional environment" is also represented by the variable "Institutions".

According to the obtained new variables of Factor 1 and Factor 2, the fundamental elements (the basic conditions for social life) of the innovative environment, in particular the "Institutions", influence the decisions of enterprises to invest in the innovative activity of all groups of countries. However, let's note that the eigenvalues of the variables that make up Factor 1 "Institutional environment and business" of a group of high-income countries explain $44.70 \%$ of the total variation, reflecting the significance of a certain factor.

For middle- and lower the middle-income countries, only $20.60 \%$ and $25.69 \%$, respectively, of the variation in the source data for the "Institutions" of Factor 2 "Institutional Environment" explain. The strengths of the national innovative system of these groups of countries are "Human Capital and Research", "Market Development", "Business Development" and "Human Capital 
and Research", "Infrastructure" (Factor 2 "Scientific and production environment" $44.80 \%$ and $39.76 \%$ ), respectively.

Also let's note that the factor load factor variable "Market Development" of Factor 1 for the group of middle-income countries has the greatest factor load among the set of variables. Proceeding from the fact that the countries represented by the representative sample (China, Bulgaria, Malaysia, Romania, Turkey, Thailand) had rapid economic and innovative development, which provided them with leading positions according to the experts of the LOSAN Business School INSEAD (Global Innovation Index) among the countries the group with incomes above the average (the average score for the countries in $2011-2017$ is 49.42 , the minimum score is 41.8 maximum - 63.9), let's conclude that the indicators of the financial market (credit, investments, market capitalization, supply venture capital) product market (trade, competition) and the effectiveness of the legal system (investor protection). This is due to the fact that technological development alone can't provide economic growth, it requires significant investments through the mechanisms of the financial market and the provision of investment liquidity.

Insufficient development of financial markets in countries with economies in transition (Vietnam, Ukraine, Armenia, India, Philippines, Indonesia) does not mean that these markets do not affect economic growth (factor loadings of variable "Market Development" is 0.63 ). The growth in lending and financing in the process of restructuring production is of stimulating importance for balanced economic growth, accelerating the accumulation of fixed capital and increasing production efficiency. The main feature of the markets of countries with economies in transition is low monetization and weak financial flows, one of the reasons for which is a rigid anti-inflationary policy.

Let's note that the data of the Global Innovation Index, which use during the research, do not reflect the hierarchy of priorities of the state innovative policy, since they have elements of a certain fragmentation aimed at determining the factors of innovative development of countries (the country's innovative potential and the conditions for its implementation). In this regard, the question arises of calculating an integral indicator that takes into account the synthetic approach to determining the priority of development of the content elements of the national innovative system of the country and highlighting the importance of the state, human capital, research, financial and commodity markets in the balanced economic growth of the country:

The main advantage of calculating the integral indicator is, in the author's opinion, the ability to compare the degree of development of each component of the innovation policy of different countries in the dynamics with a view to further making sound management decisions to identify sources and priorities for financing innovative development. Taking into account that the complex characteristic of the national innovative system of the country provides for the use of indicators, comprehensively highlights the features of the state innovation policy and the organic interrelationship of individual indicators, the development of a methodical approach is proposed to be carried out using taxonometric analysis. The construction of an integrated indicator of the assessment of the national innovative system of countries provides for the use of an international comparison base (the Global Innovative Index, the Global Competitive Index, The Bloomberg Innovation Index and the Forbex World's Most Innovative Companies) in accordance with the components of the state innovation policy:

- the basic institutions of the state (protection of intellectual property, the quality of prof tection of investors' and property rights, barriers to the export of products, ease of registration of enterprises, simplicity of taxation, efficiency of public administration);

- knowledge (expenses for education, quality of research institutes, the place of the country in the ranking of QS universities, international cooperation of institutes, accessibility of training services, graduates of engineering and scientific specialties);

- culture (degree of hierarchy, degree of individualism, degree of ambition, degree of praga matism);

- infrastructure (access to information and communication technologies, quality of logistics services, environmental policy assessment);

- financial markets (availability of financing (venture capital, private equity, borrowing)); 
- commodity markets (intensity of competition, level of development of clusters);

- financing of basic research (state expenditures on R \& D in research institutes and higher educational institutions);

- financing of innovative companies (state spending on R \& D in the private sector, financh ing of R\&D by business).

The use of the data of the proposed integrated indicator of the national innovative system of Ukraine will be an effective tool for identifying priority tools of the state innovative policy necessary for the development of the innovative environment.

\section{Discussion of results}

In connection with the strengthening of the role of innovative development in society, the study of the main criteria of innovative development indexes is becoming topical. Let's agree with the authors' opinion [26] that experts from many international organizations are developing innovation development indices that are of an applied nature, highlight the main results of theoretical studies and methodological improvements in practice.

Proceeding from the fact that innovative development is a complex and multifaceted process, the scientist [27] proposes to strengthen the influence of innovative factors on the development of the national economy of Ukraine: to form an institutional environment favorable to the development of innovation and technological activity, to increase the amount of allocations for scientific research and scientific technical develop, strengthen the role of business in providing funding for scientific, technical and innovation processes.

With the research results of the innovative national system of Ukraine and the countries of the European Union, economists [28] came to the conclusion that the choice of indicators for the evaluation of innovative policy is a big problem, and the available mechanisms for creating knowledge and innovations require the use of different indicators.

Analyzing the activities of the state on the development of a knowledge-based economy, the researchers [29] note the need to take into account such fundamental points as: the state's interest in the innovation process and the organization of a control system for effective management, use of innovation results and feedback from the subjects of all levels of the economy, with which we can't agree.

According to the experts of the European Union, by 2020 Ukraine has the opportunity to gain leadership in the group of countries "Moderate Innovators" (according to the European innovation board score). This contributes to the outline of the priorities for building innovative capacity at the macro and micro level, in particular, the creation of a managed innovation model of the country's development through the approval of national priorities, the launch of strategic development programs, the unification of domestic scientific developments, personnel support, the production sector and business.

To the abovementioned opinions of scientists, let's add that the deterrent factors in the development of the national innovative system that provides the conditions for innovation in Ukraine is the lack of funding sources, the high cost of credit, the devaluation of the national currency, the imperfect legal framework, the low level of investor confidence, the lack of incentive measures for innovation similar. This actualizes the issue of determining a set of indicators, which, on the one hand, reflect all stages and stages of scientific, technical and innovation activities, results and impact on the development of the country's economy. On the other hand, aimed at improving the criteria and principles of the hierarchy of priorities for supporting innovation by the state, business and financial market.

\section{Conclusions}

1. It is substantiated that the scientific and innovative way of development of economic syss tems is objectively the initial stage of the formation of a postindustrial society. Overcoming the economic development gap between Ukraine and developed countries, maintaining competitiveness in the global economy, ensuring the stable development of the Ukrainian economy, it is necessary to consistently pass through the stages (restoring economic growth, achieving high rates and 
quality of economic growth, sustainable development) of balanced economic growth, an increase in the quality of life, an increase in aggregate factor productivity.

2. It is proved that innovative development of the country is provided by an innovative environment, the main components of which are internal (innovative potential) and external (national innovative system) environment.

3. It is determined that the state, as the main subject of the country's innovative activity, ensures the implementation of innovative processes and legal regulation of relations. The peculiarity of state regulation of high-income countries is determined by the balance of innovative policy instruments. The institutional environment ensures the effectiveness of financial support of the business, obtaining high results from innovations and retaining the leading position on innovative development.

State regulation of innovative development in groups of countries with incomes above and below the average is considered as a secondary component of the national innovative system. To make decisions on investment in innovative activities and further innovative development, financial markets, commodity markets and the effectiveness of the legal system are of great importance. For low-income countries, market development has a stimulating effect on economic growth.

4. Fragmentation of the definition of factors of innovative development according to the Globt al Innovation Index gave grounds to provide recommendations (integral indicator) for determining the degree of priority development of the content elements of the national innovative system, which will help determine the main tools of innovative policy and the criteria for their evaluation.

\section{References}

[1] Garnov, A. Formirovanie innovatsionnoy sredy obrabatyvayushhego proizvodstva v sovremennykh ekonomicheskikh usloviyakh [The Innovative environment formation of the manufacturing in the current conditions of Economy]. Available at: https://ibn.idsi.md/sites/default/files/imag_file/Formirovania \%20 innovationnoi $\% 20$ sredi $\% 20$ obrabativaiuscego $\% 20$ proizvodstva $\% 20 \mathrm{v} \% 20$ sovremennih $\% 20$ economiceskih \%20usloviah.pdf

[2] Heiets, V., Seminozhenko, V. (2006). Innovatsiini perspektyvy Ukrainy [Innovation prospects of Ukraine]. Kharkiv: Konstanta, 272.

[3] Hrishnova, O., Pasieka, S., Pasieka, A.; Hrishnova, O. (Ed.) (2011). Trudovyi potentsial Ukrainy: otsinka stanu, efektyvnist' vykorystannia, stratehichni napriamy rozvytku [Labor potential of Ukraine: assessment of the state, usage effectiveness, strategic directions of development]. Cherkasy: TOV Maklaut, 360.

[4] Schlaile, M., Urmetzer, S., Blok, V., Andersen, A., Timmermans, J., Mueller, M. et al. (2017). Innovation Systems for Transformations towards Sustainability? Taking the Normative Dimension Seriously. Sustainability, 9 (12), 2253. doi: 10.3390/su9122253

[5] Saarinen, J., Rilla, N., Loikkanen, T., Oksanen, J. (2006). Innovation environment today and tomorrow. Jaakko Alasaarela ZEF Solutions Ltd, 32. Available at: http://www.vtt.fi/inf/pdf/workingpapers/2006/W49.pdf

[6] World Economic Situation and Prospects (2018). New York: United Nations, 188. Available at: https://www.un.org/development/desa/dpad/wp-content/uploads/sites/45/publication/WESP2018_Full_Web-1.pdf

[7] New economic growth: the role of science, technology, innovation and infrastructure (2017). G7 Academies Joint Statements. Available at: https://royalsociety.org/ /media/about-us/international/g-science-statements/2017-may-3-new-economic-growth.pdf?la=en-GB

[8] Hilbers, P. (2004). Interaction of Monetary and Fiscal Policies: Why Central Bankers Worry about Government Budgets. Available at: https:/www.imf.org/external/np/leg/sem/2004/cdmfl/eng/hilber.pdf

[9] Bianchi, F., Melosi, L. (2017). The Dire Effects of the Lack of Monetary and Fiscal Coordination. Available at: https://economics.indiana.edu/home/about-us/events/conferences-and-workshops/ files/2017-03-02-01.pdf

[10] Ukraina 2030: Doktryna zbalansovanoho rozvytku [Doctrine of the balanced development] (2017). Lviv: Kal'variia, 164.

[11] Zvejarkov, M. (2017) Globalizacija i deindustrjalizacija: soderzhane, protivorechija i sposobiih reshenija [Globalization and de-industrialization: nature, contradictions and ways of resolving]. Ekonomyka Ukrayny, 5-6, 1-11. 
[12] Slatvynskyi, M. (2013). Problemy formuvannia spryiatlyvoho innovatsiinoho seredovyscha v Ukraini [The Problems of Formation of the Favourable Innovative Environment in Ukraine]. Available at: http://dspace.udpu.org.ua:8080/jspui/bitstream/6789/459/1/Innovats_seredovyshche.pdf

[13] Posokhov, I., Kabysh, H. Yu., Khodyrieva, O. O. (2017). Problemy rozvytku innovatsijnoho seredovyscha [The Problems of the Innovative Environment Development]. Problemy formuvannia ta rozvytku innovatsiinoi infrastruktury: vyklyky postindustrialnoi ekonomiky. Lviv: Vyd-vo Lvivskoi politekhniky, 818-819. Available at: http://repository.kpi.kharkov.ua/bitstream/KhPI-Press/30668/1/Posokhov_Problemy_rozvytku_2017.pdf

[14] Karpun, I. (2010). Struktura i seredovysche natsional'noi innovatsijnoi systemy Ukrainy [Structure and environment of the National innovation system in Ukraine]. Naukovyi visnyk NLTU Ukrainy [Scientific bulletin of NLTU Ukraine], 20 (14), 193-200. Available at: http://nltu.edu.ua/nv/Archive/2010/20_14/193_Kar.pdf

[15] Dubischev, V., Kraus, N. (2015). Innovatsiina ekonomika ta ii instytutsionalizatsiia [The Innovative Economy and the Process of its Institutionalization]. Poltava NTU: Ekonomika i rehion [Poltava NTU: Economy and Region], 3 (52), 22-27. Available at: http://77.121.11.9/bitstream/PoltNTU/2917/1/\%D0\%94 $\% \mathrm{D} 1 \% 83 \% \mathrm{D} 0 \% \mathrm{~B} 1 \% \mathrm{D} 1 \% 96 \% \mathrm{D} 1 \% 89 \% \mathrm{D} 0 \% \mathrm{~B} 5 \% \mathrm{D} 0 \% \mathrm{~B} 2 . \mathrm{pdf}$

[16] Fedirko, O.; Lukianenko, D. H., Poruchnyk, A. M. (Eds.) (2006). Natsional'ni innovatsiini systemy krain vysokoho konkurentnoho statusu [National innovation systems of the high competitive status countries]. Upravlinnia mizhnarodnoiu konkurentospromozhnistiu v umovakh hlobalizatsii ekonomichnoho rozvytku. Vol. 1. Kyiv: KNEU, 679-685.

[17] Edquist, C. (2001). The Systems of Innovation Approach and Innovation Policy: An account of the state of the art. Available at: http://www.obs.ee/ siim/seminars/edquist2001.pdf

[18] GII Framework (2017). The Global Innovation Index. Available at: https://www.globalinnovationindex.org/about-gii\#framework

[19] Andrew, J. P., DeRocco, E. S., Taylor, A. (2009). The innovation Imperative in Manufacturing. How the United States Can Restore. Its Edge Report BGC, 32. Available at: http://www.themanufacturinginstitute.org/ /media/6731673D21A64259B081AC8E083AE091.ashx

[20] Lopez-Claros, A., Mata, Y. N. (2010-2011). Innovation Capacity Index. Available at: http://innovationfordevelopmentreport.org/ici.html

[21] European Innovation Progress Report 2006 (2006). Luxemburg: Office for Official Publications of the European Communities, 252.

[22] The Global Innovation Index. Analysis (2017). Available at: https://www.globalinnovationindex.org/analysis-indicator

[23] The Global Innovation Index (2017) Report. Available at: https://www.globalinnovationindex. org/gii-2017-report

[24] The Global Innovation Index (2011-2016). Past Reports. Available at: https://www.globalinnovationindex.org/about-gii\#reports

[25] Total Economy Database ${ }^{\mathrm{TM}}$. Growth Accounting and Total Factor Productivity, 1990-2016 (2017). The Conference Board Trusted Insights For Business Worldwide. Available at: http://www.conference-board.org/data/economydatabase/

[26] Hernenko, Yu., Pidhoretska, S. M. (2014). Indeksy innovatsiinoho rozvytku krain svitu [Indices of the World`s innovation development]. Universytets'ki naukovi zapysky [University scientific notes], 1 (49), 339-346.

[27] Radchenko, L. (2015) Innovatsiinyi rozvytok natsional'noi ekonomiky ta mekhanizmy ioho zabezpechennia [Innovative development of the National Economy and the Mechanisms of its Support]. Zbirnyk naukovykh prats' Kharkivs'koho natsional'noho pedahohichnoho universytetu im. H. S. Skovorody «Ekonomika» [Collection of scientific works of the Kharkov National Pedagogical University G. S. Skovoroda. Economics], 15, 159-167.

[28] Maltsev, V. S., Koreniako, H. I. (2013). Porivnialna otsinka innovatsiinoho rozvytku rehioniv Ukrainy z vykorystanniam dosvidu Yevrosoiuzu [Comparative evaluation of the innovative development of the Ukraine's regions according to profound experience of the European Union]. Rehional'na ekonomika [Regional Economy], 1, 51-59.

[29] Baula, O., Savosch, L., Liutak, O. (2017). Perspektyvy innovatsijnoho rozvytku ekonomiky Ukrainy u konteksti innovatsijnoho tablo YeS [Perspectives of the innovative development of the Ukraine`s economy in context of the Innovation EU scoreboard]. Naukovyi visnyk Uzhhorods'koho natsional'noho universytetu [Scientific bulletin Uzhhorod National University], 12 (1), 24-28. 